\title{
Miscellaneous notes
}

\author{
VARIOUS AUTHORS
}

TWO NOMENCLATURAL PROBLEMS INVOLVING ARTICLE 63

While preparing a course in plant nomenclature in 1982, I endeavoured to find examples of superfluous names in South African taxonomic literature. Among others, I found the following two cases but, in the first, the rules, since the 1987 Berlin Congress, have changed to make the second option in the example a case of later synonymy rather than superfluity. However, it is such an interesting case, that it deserves mention.

\section{Silene dewinteri or $S$. constantia?}

Bocquet in Bothalia 12: 309-311 (1977) described Silene dewinteri as a new species with Bocquet 17774 as holotype. He cited in synonymy ' $S$. constantia Eckl. \& Zeyh., Enum. 32 (1834) quoad descr., typo et synonymia excludendis'.

In their protologue of $S$. constantia, Ecklon \& Zeyher included, in synonymy, $S$. crassifolia L. var. angustifolia Bartl. (1832), based on Ecklon specimen/s from the vicinity of 'uppermost blockhouse' at Devil's Peak. Bocquet in his "Observations" on $S$. dewinteri stated that because Ecklon \& Zeyher cited S. crassifolia var. angustifolia in synonymy under $S$. constantia the latter was 'automatically typified by the type of the variety'. According to Dr R. K. Brummitt of Kew, this could be construed to constitute lectotypification of $S$. constantia by the Ecklon 'blockhouse' specimen/s which, however, Bocquet referred to $S$. clandestina Jacq. However, it is not certain whether this does constitute lectotypification because, by definition (Article 7.5 of the International code of botanical nomenclature, 1988), a lectotype can only be a single specimen or illustration and Bocquet clearly referred to specimens (plural). Unfortunately in Bartling's description of $S$. crassifolia var. angustifolia there is no indication of whether the varietal name is based on one or more Ecklon specimens. I have corresponded with Mr Daniel Masson of Geneva $(G)$, who is continuing with Bocquet's revision of the southern African species of Silene, to establish whether one or two specimens were involved and whether there were annotations by Bocquet on the specimen/s. In his reply (letter of 1988. 10.08) Masson mentions that he has two specimens on loan from Stockholm which may be relevant. The first is an Ecklon specimen bearing the names $S$. crassifolia var. angustifolia (det. Bartling, 1831) and S. thunbergiana. No locality is given, but the label carries the number 53 which may refer to 'Stellenbosch, Houwhoeksbergen', if it relates to the Ecklon \& Zeyher localities listed by Drège in Linnaea 19: 583-598 (1847). The second specimen, anonymous as to collector, bears three names viz. S. flexuosa (ined.), S. crassifolia var. angustifolia and $S$. constantia. The number 85 appears on the sheet and if it is an Ecklon \& Zeyher number (as listed by Drège in Linnaea 20: 258 (1847), it refers to 'eastem side of Table Mountain at Constantia'. Masson identifies this specimen as $S$. clandestina and suggests that it is an Ecklon specimen. However, if the number 85 is an Ecklon \& Zeyher number, then the locality is incorrect for the type of $S$. crassifolia var. angustifolia. The same applies to the first specimen. On the evidence available, it seems doubtful whether either specimen is the Ecklon type of $S$. crassifolia var. angustifolia from the 'uppermost blockhouse' at Devil's Peak. Neither specimen has been annotated by Bocquet-let alone as lectotype of $S$. constantia.

Therefore, there are two aspects to the Silene dewinteri versus $S$. constantia problem, one in which the lectotypification is regarded as having been effected and the other not. The two aspects will be examined in turn.

\subsection{Lectotypification effected}

This situation concerns lectotypification of Silene constantia irrespective of whether it is correct or not. Bocquet clearly stated that the description of $S$. constantia, but not the type, agreed with his concept of $S$. dewinteri. In short, he admitted a discrepancy or conflict between the designated lectotype of $S$. constantia and its protologue, specifically the description. What are the practical implications of these facts? Two implications come to mind: 1, if one ignores Bocquet's incorrect lectotypification of $S$. constantia, then $S$. dewinteri remains a correct name and $S$. constantia remains a synonym of $S$. clandestina; 2 , if one rectifies the lectotypification, then $S$. constantia becomes the correct name and $S$. dewinteri a later legitimate synonym in the context of Note 2 of Article 63.1 (a superfluous name pre-the 1987 Berlin Congress). There is no problem in designating a new lectotype of $S$. constantia. Ecklon and Zeyher in describing $S$. constantia clearly used their own gathering Ecklon \& Zeyher s.n.: the specimen agrees with the description and was collected near Constantia and Hottentots Holland. However, such a step, if considered advisable, is best left to someone working on the genus.

An obvious question arises. Why did Bocquet assert that $S$. constantia was automatically typified by the type of the cited synonym, $S$. crassifolia var. angustifolia? A possible explanation is that Bocquet erroneously invoked Article 7.11 (previously 7.9), which states that 'a nomen novum for an older name is typified by the type of the older name'. The way in which Bocquet phrased the typification, viz. "typified by the type of the variety (older name*)' seems to point to this. It is doubtful whether Bocquet, in spite of possibly effecting lectotypification, deliberately intended lectotypifying $S$. constantia. Significantly, he did not use the word 'lectotypification'.

* my parenthesis 


\subsection{Lectotypification not effected}

In this case one has the option of designating a lectotype for $S$. constantia, but this is not mandatory (Article 7.5 and Recommendation 7B). If a lectotype is designated, the Ecklon \& Zeyher s.n. specimen mentioned above would be a good choice. The result of this action, as already indicated, would be that $S$. constantia becomes the correct name and $S$. dewinteri a later synonym.

\section{Antholyza caffra}

In a note on Anapalina caffra (Ker ex Bak.) Lewis in Journal of South African Botany 37: 235 (1971) Goldblatt states that Antholyza caffra Ker ex Bak. (1892) was not a superfluous name, even though the earlier Anisanthus splendens Sweet (1831), a misidentification, was cited in synonymy and he cites Stafleu's interpretation of the Seattle modification of Article 63 in support [see Stafleu in Taxon 19:41-42 (1970)]. The Seattle modification relates to the explicit or implicit exclusion of the type of the cited name. Stafleu interprets this as follows: 'When it can be shown that the type of a cited name cannot within reason have been included by the author within the circumscription of his new taxon, his name does not become automatically superfluous on account of the mere citation of the older name'. Goldblatt writes: 'As Baker probably named this plant Antholyza caffra thinking that Ker's name had priority over Anisanthus splendens and because the latter cannot be included in Baker's circumscription of this species the question of superfluity cannot really be raised, particularly if Stafleu's interpretation of the modification of Article 63 is followed'.

Let us analyse Goldblatt's statement. Firstly, he states that superfluity is not at issue because Baker believed that Antholyza caffra Ker (1805) had priority over An- isanthus splendens (1831). But Antholyza caffra Ker was a nomen nudum and therefore not validly published. By supplying a description Baker validated the name for the first time and by citing Anisanthus splendens as a synonym ['the citation of the name itself' (Article 63.2)] without excluding its type either explicitly or implicitly (there is no evidence of such exclusion) the name Antholyza caffra becomes superfluous. Secondly, Goldblatt asserts that because Anisanthus splendens, as figured and described by Sweet, cannot be included in Baker's circumscription of Antholyza caffra, the question of superfluity cannot be raised. The fact is that whatever taxonomists of today think about the relationship between the two species, Baker himself regarded Antholyza caffra as conspecific with the earlier Anisanthus splendens. This is not surprising if, as pointed out by Goldblatt, 'the plants are similar', though they are now known to belong to different genera. Weresub \& Hennebert [Taxon 12,6: 218-228 (1963)] would call this a case of facultative superfluity involving a facultative synonym as opposed to nomenclatural superfluity involving an obligate synonym.

Clearly there seems to have been a misinterpretation of the Seattle modification of Article 63, since the question of explicit or implicit exclusion does not arise at all. What is the implication of Antholyza caffra being superfluous? The name Antholyza caffra, being illegitimate, the epithet caffra can only be used in Anapalina if the combination Anapalina caffra is treated as new dating from 1960 and attributed solely to Lewis.

I thank Dr R. K. Brummitt of the Royal Botanic Gardens, Kew, for helpful comments on these two cases.

D. J. B. KILLICK

MS. received: 1988.02.15 